Niepełnosprawność. Dyskursy pedagogiki specjalnej

Nr 32/2018

Disability. Discourses of special education

No. 32/2018

Jolanta Rzeźnicka-Krupa

Uniwersytet Gdański

\title{
Oswajanie rzeczywistości: realizm i magia w twórczości literackiej Aliny Domnicz
}

\author{
„[...] czym jest bowiem sztuka? [...] uprawiana przez tych, \\ których - bez cienia wartościowania i wyższości - \\ nazywamy autorami? \\ Okazuje się, że u jej podstaw leży to samo \\ (tak podziwiane w sztuce uznanych mistrzów) \\ pragnienie uczynienia świata bardziej znośnym, \\ oswojonym przez naszą wyobraźnię, \\ słowo, twórczy akt kreacji". \\ Paweł Huelle ${ }^{1}$
}

W prezentowanym tekście przedstawiona została analiza twórczości literackiej Aliny Domnicz, mieszkanki ekumenicznej wspólnoty L'Arche w Śledziejowicach pod Krakowem, skoncentrowana wokół zasadniczego pytania: Jaki świat kreuje Autorka w swoich utworach i w jaki sposób to robi? Głównym celem artykułu jest zatem poznanie literackich światów konstruowanych przez Autorkę oraz środków, za pomocą których są tworzone. Podejściem badawczym, umożliwiającym realizację tak określonego celu jest jakościowa analiza treści (tekstu) oraz analiza narracyjna wybranych utworów literackich. Przy czym tekst narracyjny, za M. Balem, definiuję jako tekst, w którym podmiot lub agens przekazuje odbiorcy („opowiada" czytelnikowi) opowieść za pomocą określonego medium, np. języka, obrazów, dźwięków [Bal 2012: 3]. Ramą interpretacyjną, tworzącą szerszy, teoretyczno-literacki kontekst badań, jest nurt magicznego realizmu. Analizując opowiadania, poszukiwałam w nich zatem wątków i motywów charakterystycznych dla tego nurtu, które pomogły wyłonić wyodrębnione w toku analizy kategorie opisu. Alina Domnicz, w poddanych analizie Opowiadaniach, używa niezbyt skomplikowanego, dość potocznego, a miejscami nawet lekko rubasznego języka, zamykającego się w stosunkowo niewielkim zbiorze pojęć, zwrotów i zdań. Jednak za pomocą prostego, pozbawionego intelektualnego wyrafinowania i estetycznych eksperymentów tworzywa, potrafi wykreować coraz to bardziej złożoną, nabierającą magicznego wymiaru rzeczywistość. Wprowadza w tok opowieści, dozując niejako stopniowo napięcie, niezwykłych bohaterów, których umieszcza w pozornie zwyczajnych i naturalnych, ale zarazem też dziwnych i niezwykłych sytuacjach.

Słowa kluczowe: sztuka, twórczość, literatura, niepełnosprawność, język

1 P. Hulle, Przedmowa [w:] A. Domnicz, Opowiadania, Gdańsk 1996, s. 3. 


\title{
Familarizing reality: realism and magic in literary creativity of Alina Domnicz
}

\begin{abstract}
The article is a presentation of the analysis of literary creativity of Alina Domnicz, a woman with intellectual disability and autistic spectrum disorders, living in one of the ecumenic community L'Arche in Poland. The research was aiming to see what kind of world is created by the Authoress in her stories and what literary means she uses? In order to realize the goal the method of content (text) analysis and narrative analysis was used, according to the assumption that the subject telling the stories with the medium of language, images or sounds is what makes the narrative text. The wider theoretical frame of interpretation referred to magic realism, a literary current combining some realistic and magical features of the world presented in artistic works. In the analysed collec-tion of stories Alina Domnicz does not uses very sophisticated but rather colloquial or even coarsy language, limited to relatively small set of concepts, phrases and sentences. But using such a simple rather than sophisticated means, she successfully creates more and more complex reality, which gradually is becoming magical.
\end{abstract}

Keywords: art, creativity, literature, disability, language

\section{Literackie światy Aliny Domnicz - wprowadzenie}

W prezentowanym tekście chciałabym przyjrzeć się bliżej wybranym tekstom literackim tworzonym przez Alinę Domnicz, mieszkankę Wspólnoty L'Arche² w Śledziejowicach pod Krakowem. Wspólnota powstała we wrześniu 1981 r. jako pierwsza z kilku funkcjonujących obecnie w Polsce, a Alina Domnicz mieszka w niej niemal od początku, tj. od 1982 r. Autorka urodziła się w maju 1964 r. w Krakowie, tam też uczęszczała do szkoły podstawowej i specjalnej szkoły zawodowej, której jednak nie ukończyła. W trakcie pobytu we wspólnocie rozwinęła swoje pasje artystyczne, literackie i plastyczne. Miała zorganizowane wystawy malarskie między innymi w galeriach w Krakowie, Warszawie i Gdańsku. Jej pierwsze utwory literackie, bajki i opowiadania, zaczęły po-wstawać w 1985 r., autorka zapisuje je ręcznie w zeszytach, które dodatkowo ozdabia własnoręcznie wykonanymi, kolorowymi ilustracjami3 ${ }^{3}$ W artykule zamieszczam kilka fotografii przedstawiających strony z oryginalnych brulionów autorki ${ }^{4}$.

2 L'Arche to międzynarodowa federacja ekumenicznych wspólnot, w których przebywają wspólnie pełnosprawni asy-stenci oraz osoby z niepełnosprawnością intelektualną. Misją wspólnot jest ukazywanie wartości każdej osoby bez względu na sprawność intelektualną oraz budowanie relacji. Twórcą idei leżących u podstaw filozofii działania ruchu wspólnotowego oraz założycielem pierwszej wspólnoty w Trosly-Breuil pod Paryżem w 1964 r. był Jean Vanier. Obecnie w Polsce, Fundacja L'Arche, poza Śledziejowicami, prowadzi wspólnoty w Warszawie, Poznaniu, Wrocławiu i Gdyni; www.larche.org [dostęp: 15.09.2018].

3 Informacje zostały zaczerpnięte z artykułu A. Szemplińskiej i K. Chatzipentidis, Zastosowanie biblioterapii w pracy z osobami niepełnosprawnością intelektualną na przykładzie wspólnoty L'Arche, 2017, s. 166-168, a także ze strony internetowej L'Arche International, www.larche.org [dostęp: 15.09.2018] (tłum. własne).

4 Prezentowane $\mathrm{w}$ artykule fotografie zostały udostępnione dzięki uprzejmości i za zgodą pani Aliny Domnicz. Autorem zdjęć jest Rafał Ślusarczyk, dyrektor Wspólnoty L'Arche w Śledziejowicach. 


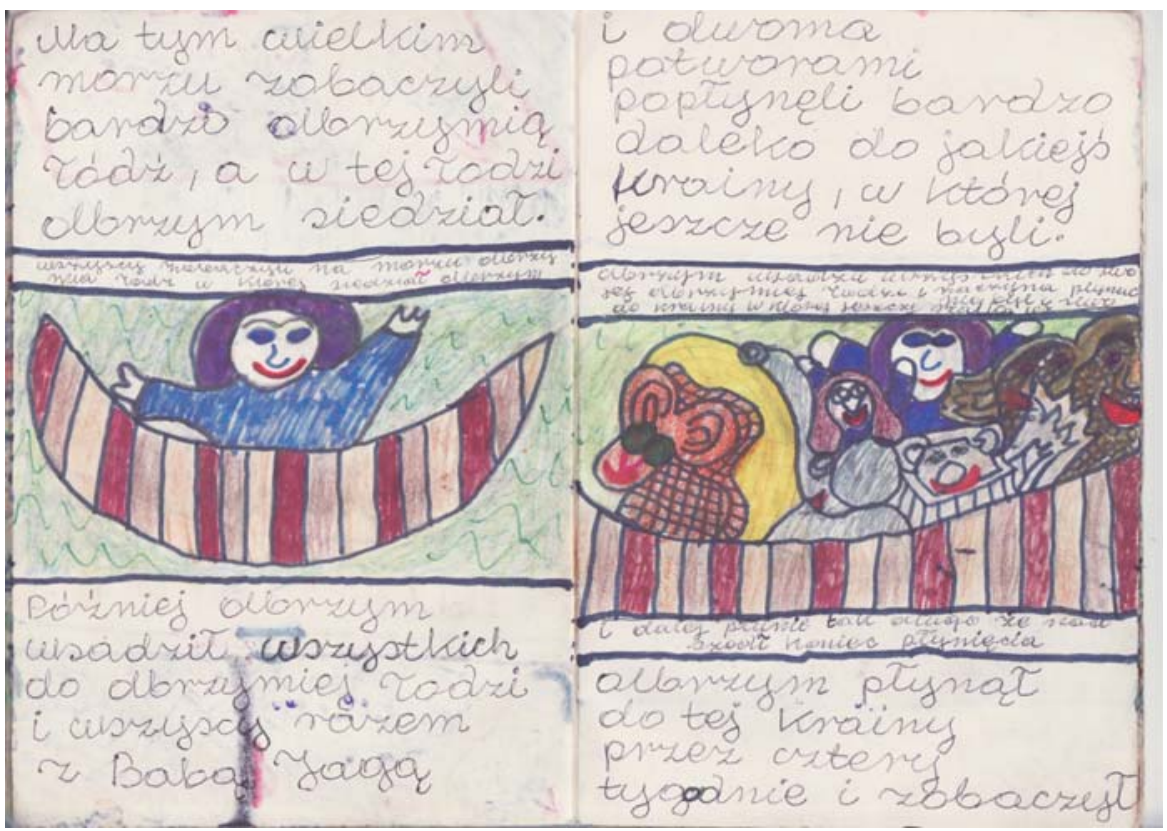

\section{Fotografia 1}

Źródło: Rękopisy Aliny Domnicz (własność autorki, zdjęcia: Rafał Ślusarczyk)
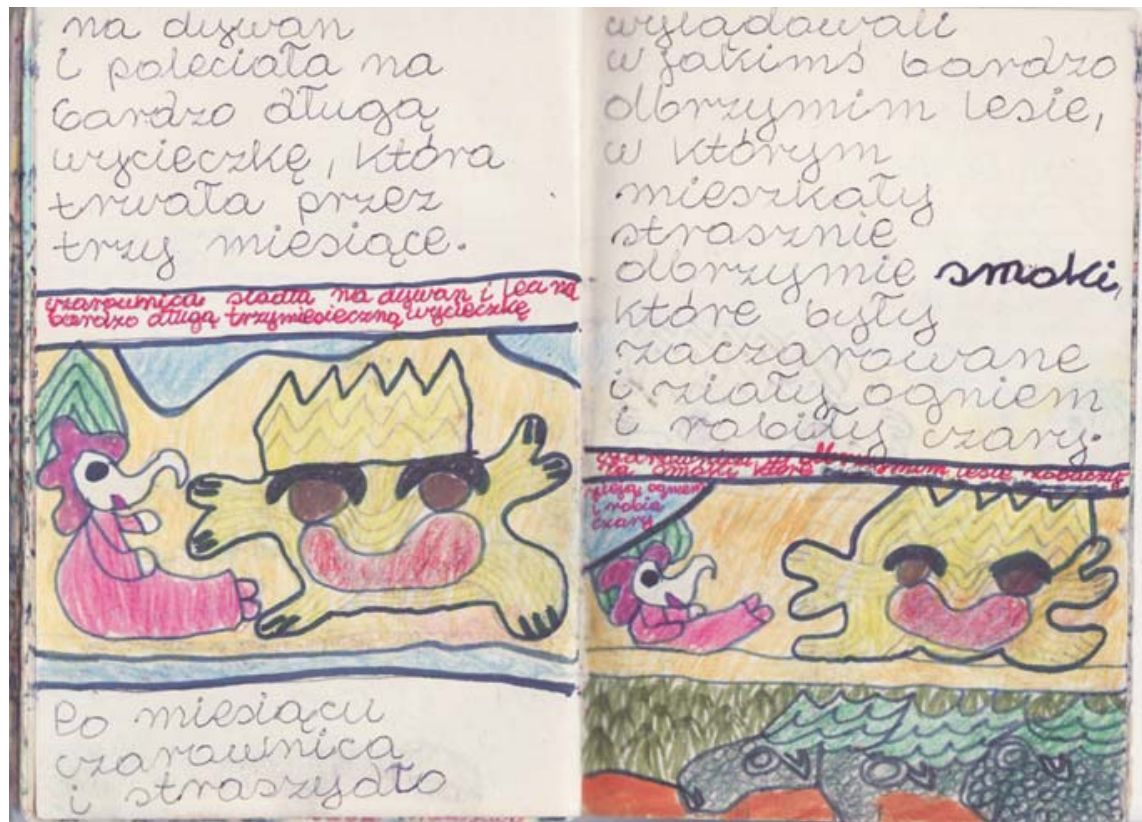

Fotografia 2

Źródło: Rękopisy Aliny Domnicz (własność autorki, zdjęcia: Rafał Ślusarczyk) 
Twórczość, której tworzywem jest język i osadzone w nim narracje, stosunkowo rzadko staje się motywem artystycznych wypowiedzi osób z niepełnosprawnością intelektualną. Społeczne i kulturowe konstrukcje niepełnosprawności intelektualnej zazwyczaj akcentują nacechowaną negatywnie odmienność, wynikającą z wielu ograniczeń związanych ze sferą poznawczą i językową. D. Krzemińska, badaczka języka i dyskursu dorosłych osób z niepełnosprawnością intelektualną, zwraca uwagę na rozdźwięk pomiędzy wiedzą wyłaniającą się z analizy literatury naukowej na temat sfery funkcjonowania językowego tej grupy, a tym co prezentują teksty napisane przez niepełnosprawnych twórców (np. bajki Aliny Domnicz, Mruczanki Śledziejowickie Karola Nahlika czy wiersze Haliny Gadaszewskiej). Twórczość wymienionych artystów wydaje się podważać dość powszechne przekonanie na temat osób z niepełnosprawnością intelektualną jako tych, którzy mają znacząco ograniczone możliwości wyrażania własnych myśli, zdolności do refleksji nad rzeczywistością czy też jej rozumienia [Krzemińska 2012: 10-16]. Pisząc o twórczości Karola Nahlika, w innym tekście, D. Krzemińska określą ją jako „....zapis rozmaitych rozważań, myśli, pytań, komentarzy do zdarzeń czy przeczytanych fragmentów książek - słowem pewnego rodzaju dziennik, w którym autor uzewnętrznia i dzieli się tym, w jaki sposób przeżywa rozgrywającą się rzeczywistość" [Krzemińska 2013: 82]. W zetknięciu z tą twórczością, choć - jak zauważa autorka - bywa ona dość specyficzna z powodu pewnych niedoskonałości językowych - narzucająca się niejako oczywistość „nienormalności” współistniejącej z zespołem Downa również zdaje się być kwestionowana" [tamże: 84].

Twórczość literacka Aliny Domnicz wzbudziła już wcześniej zainteresowanie badaczy. E. Ziarkiewicz i A. Szemplińska poddały analizie 25 bajek zapisanych ręcznie w brulionie "dedykowanym Ewelince" [Zierkiewicz, Szemplińska 2015: 123-141]. Ich bohaterkami są wiedźmy, postaci budzące negatywne emocje, takie jak strach czy odraza. Można powiedzieć, że prezentują swego rodzaju antywzory osobowe istot wykluczanych ze społeczeństwa bądź też wypełniających nieakceptowane społecznie role. Autorki artykułu stawiają tezę, iż Alina Domnicz, poprzez centralną postać Baby Jagi/Wiedźmy, która podróżuje i przechodzi liczne transformacje, doświadcza poczucia sprawstwa poszerzającego granice jej własnej, podmiotowej wolności, a także wyraża niezgodę na bycie piętnowaną i klasyfikowaną jako Inna. Ich zdaniem, autorka pisząc bajki, podejmuje rodzaj autoterapii, a poprzez symbole i fantazję - opowiada o sobie, własnych marzeniach, pragnieniach i sposobach radzenia sobie w codziennym życiu. Twórczość Aliny Domnicz jest interpretowana jako wypowiedź na temat jej tożsamości społecznej i sposób regulowania własnego życia emocjonalnego. Postać Baby Jagi to literackie alter ego autorki, zaś bajki stanowią jedną ze strategii adaptacyjnych i jednocze- 
śnie rekonstruujących społeczne dyskursy dotyczące kobiecości, dojrzałego wieku i niepełnosprawności.

E. Ziarkiewicz i A. Szemplińska, przyjmując założenie o silnym związku między narracją i życiem, proponują interpretację, w której analizowane bajki są z jednej strony wyrazem akceptacji własnej inności przez autorkę (obdarzoną potrójnym piętnem niepełnosprawności intelektualnej, brzydoty ciała związanej z chorobą i dojrzałym wiekiem, a także piętna bycia kobietą), z drugiej zaś swoistym demontażem układów społecznych, w ramach których wytwarzane są i przypisywane różnorodne stygmaty, naznaczające negatywnie tożsamość podmiotów. Poprzez wybór głównej bohaterki oraz przedstawienie jej działań, Alina Domnicz komentuje/krytykuje dominujący porządek, podejmując swoistą grę zarówno z samą formą i strukturą tradycyjnych baśni, jak i z niesprawiedliwym układem sił społecznych [tamże: 128-129]. Badaczki zwracają uwagę na fakt, że umieszczenie w centrum opowieści wątku podróży, która prowadzi zawsze do przemiany głównej bohaterki, sugerować może, że motywy twórczości Aliny Domnicz skupiają się wokół kwestii samopoznania, konfrontacji z tematami ważnymi dla osoby/kobiety w średnim wieku, przepracowaniem stygmatów, poprzez które jest postrzegana [tamże: 136].

$\mathrm{W}$ innym tekście, poświęconym biblioterapii w pracy z dorosłymi osobami z niepełnosprawnością intelektualną, A. Szemplińska i K. Chatzipentidis także podkreślają, że Alina Domnicz w swoich utworach podejmuje swoistą autoterapięi, choć nie wprost, opowiada o sobie. Wykreowana przez nią postać Wiedźmy/ Baby Jagi, pojawiająca się jako ważny motyw także w jej twórczości malarskiej, nie jest kimś „gorszym, strasznym, obcym, żałosnym czy potwornym, lecz psotnicą o dobrym sercu, która troszczy się o innych [...]". Autorzy wyrażają pogląd, że poprzez twórczość literacką osoby z niepełnosprawnością intelektualną, takie jak Alina Domnicz czy Karol Nahlik5 , mogą podejmować uniwersalną problematykę dotyczącą świata, ludzi, ludzkiej egzystencji, poznawania rzeczywistości i funkcjonowania w niej oraz opisywania jej w metaforyczny sposób za pomocą tworzywa, jakim jest język [Szemplińska, Chatzipentidis 2017: 167-168].

\section{Podstawy metodologiczne i ramy interpretacyjne analizy}

W prezentowanym tekście chciałabym przyjrzeć się twórczości literackiej Aliny Domnicz, stawia-jąc pytanie: Jaki świat kreuje w swoich utworach i w jaki sposób to robi? Poszukując tropów interpretacyjnych, do których mogłabym się odnieść,

5 Alina Domnicz i Karol Nahlik przez wiele lat byli mieszkańcami tej samej wspólnoty L'Arche w Śledziejowicach. Niestety w czerwcu 2018 r. Karol Nahlik zmarł w wieku 66 lat. 
nie chciałam powielać tego co już zostało powiedziane i napisane we wspomnianych wcześniej publikacjach. Nie chciałam także traktować twórczości Aliny Domnicz w kategoriach funkcji terapeutycznych (autoterapii, pisania ekspresyjnego), jakie pisanie może pełnić $\mathrm{w}$ odniesieniu do dorosłej, dojrzałej kobiety $\mathrm{z}$ niepełnosprawnością intelektualną i zaburzeniem ze spektrum autyzmu. Moim celem jest przede wszystkim, w odwołaniu do wybranych utworów, poznanie literackich światów wytwarzanych przez autorkę oraz środków, za pomocą których są kreowane (nawet jeśli nie są to zabiegi świadomie stosowane przez twórcę). Podejściem badawczym, umożliwiającym realizację tak określonego celu jest jakościowa analiza treści (tekstu) oraz analiza narracyjna wybranych utworów literackich. Przy czym tekst narracyjny, za M. Balem, definiuję jako tekst, w którym podmiot lub agens przekazuje odbiorcy („opowiada” czytelnikowi) opowieść za pomocą określonego medium, np. języka, obrazów, dźwięków [Bal 2012: 3].

M. Wlazło pisze, że włączenie i uprawomocnienie fikcji literackiej w obszar zainteresowań pedagogiki nie jest wyłącznie kwestią uznania zakorzenienia tej dyscypliny w humanistyce, ale wiąże się także z przyjęciem jakościowej perspektywy metodologicznej jako fundamentalnej dla określenia kulturowych aspektów procesów edukacji oraz badań intertekstualnych i interdyscyplinarnych [Wlazło 2012: 14]. Fikcja literacka nie odnosi się jednak jedynie do wizerunków i sposobów reprezentacji zjawiska niepełnosprawności przedstawianych w różnego rodzaju utworach. Obejmuje również obszar, zróżnicowanej w formie i treści, twórczości językowej samych osób z niepełnosprawnością6. Istnieje wiele metod analizowania tekstów, takich jak np. analiza treści, analiza struktur narracyjnych czyli inaczej mówiąc, semiotyczna analiza narracyjna, etnografia tekstów, etnometodologia, analiza dyskursu, krytyczna bądź historyczna analiza dyskursu [Silverman 2007: 150-154; Bauman 2001: 351-352; Perakyla 2009: 327-328]. Jakościowa analiza tekstu bierze pod uwagę występowanie pewnych charakterystycznych treści. Wyłonienie określonych wątków tematycznych czy kategorii pojęciowych, może zostać poprzedzone doborem wstępnych kategorii, które ukierunkowują pracę nad tekstem [Bauman, 2001: 351-352]; Palska 1999, za: Szczepaniak 2012: 95].

Takimi właśnie kategoriami organizującymi procesy odczytania, analizy i rekonstrukcji tekstów literackich Aliny Domnicz, były dla mnie podstawowe i poboczne motywy, charakteryzujące nurt realizmu magicznego. Tak więc ramą interpretacyjną, tworzącą szerszy, teoretyczno-literacki kontekst analizy, jest nurt magicznego realizmu, który z wielu powodów, przedstawionych w dalszej części artykułu, wydaje się być adekwatnym tłem przedstawianych dociekań badawczych. Analizując opowiadania, poszukiwałam w nich zatem wątków i motywów

6 Przykładem mogą być wspomniane przeze mnie wcześniej teksty naukowe analizujące twórczość Aliny Domnicz, czy też teksty D. Krzemińskiej odnoszące się do twórczości Karola Nahlika. 
charakterystycznych dla tego nurtu, które pomogły wyłonić wyodrębnione w toku analizy kategorie opisu.

Analizowane utwory zostały zaczerpnięte ze zbioru opowiadań, pierwotnie zapisanych w rękopisie i wydanych później w formie publikacji [Domnicz 1996]. W Przedmowie do tejże publikacji autor-stwa Aliny Domnicz, znany gdański pisarz, Paweł Huelle, zastanawiając się nad pytaniem "Czym jest sztuka?" pisze: „Zapewne aktem kreacji, stworzeniem własnego świata, którego istnienie powierzone jest materii: ludzkich słów, farb rozmieszczonych na płótnie, dźwięków muzyki zapisanych w partyturze" [Huelle 1996: 3]. Jaki zatem świat, powierzony materii słów, kreuje w swoich opowiadaniach Alina Domnicz? W jaki sposób próbuje, za pomocą wyobrażonego świata, oswoić rzeczywistość, w której żyje? Jakie są literackie cechy tego realno-magicznego świata? Szukając odpowiedzi na te pytania, wyjaśnię najpierw czym jest magiczny realizm.

\section{Magiczny realizm jako nurt w sztuce i literaturze}

Polski badacz, T. Pindel, nazywa realizm magiczny terminem „zaklęcie”. Pojęcie realizmu sugeruje literaturę opisującą rzeczywiste życie, natomiast określenie „magiczny” wskazuje na „obcowanie z niesamowitością” [Pindel 2014: 5], z czymś niezwykłym, odbiegającym od codzienności i wpisującym się w świat fantazji. Sam termin „magiczny realizm” powstał w Europie i pierwotnie użyto go w odniesieniu do malarstwa. Po raz pierwszy pojawił się w wydanej w 1925 r. pracy niemieckiego krytyka sztuki Franza Roha pt. „Nach-Expressionismus, Magischer Realismus. Probleme der neus-ten europaischen Malerei” (Post-ekspresjonizm, realizm magiczny. Zagadnienia nowego malarstwa europejskiego). Jak pisze T. Pindel, Rohe, analizując malarstwo europejskie po I wojnie światowej, określał nową sztukę jako „preferencję do zestawiania magiczności z realizmem, skłonność do wyobrażania fantastycznych przedmiotów, łączenie codzienności z zaskakującym egzotyzmem, celem było «ukazanie cudownej strony rzeczywistości»" [Pindel 2014a: 14-15; 2014b: 214-216].

W analizach literackich termin ten pojawił się w tekście włoskiego krytyka i pisarza, Massimo Bontempelli, który odrzucał zarówno tradycyjny realizm, jak i fantastykę, wskazując na możliwość łączenia tych dotychczas sprzecznych konwencji i postulując by twórczość prozatorska odkrywała magiczne aspekty codzienności, obecne w pozornie banalnych zjawiskach.

W kontekście literatury latynoamerykańskiej określenia tego użył wenezuelski pisarz Arturo Uslar Pietri w swoim eseju opublikowanym w 1948 r., zaś rozkwit literatury iberoamerykańskiej w latach 60. XX w. sprawił, że nurt magicznego 
realizmu zaczął być identyfikowany przede wszystkim z twórczością pisarzy z tego właśnie regionu. W $1967 \mathrm{r}$. badacz i znawca literatury latynoamerykańkiej, Luis Leal, definiował realizm magiczny jako pewną postawę" "[...] wobec rzeczywistości, która może być wyrażona zarówno za pomocą form ludowych, jak i wyszukanych, w stylu dopracowanym, jak i pospolitym, w strukturach zamkniętych bądź otwartych [...] nie tworzy on światów wyobraźni, do których możemy uciec przed codziennością. W realizmie magicznym pisarz wychodzi naprzeciw rzeczywistości i próbuje siegnąć do jej wnętrza, poznać tajemnicę przedmiotów, życia, ludzkich czynów". Nie można go łączyć ani z literaturą fantastyczną, nie tworzy bowiem wyimaginowanych światów i nie przekształca rzeczywistości, ani też z psychologiczną bo nie interesuje go analiza psychiki postaci bądź wyjaśnianie ich zachowań. Zdaniem Leal'a, nie jest on także ruchem czysto estetycznym, gdyż nie skupia się jedynie na formie i zabiegach stylistycznych, ani nie jest też literaturą magiczną, gdyż powinien opisywać emocje, a nie tylko je wzbudzać Pindel 2014a: 27-28; 2014b: 225-227]. Z tym nurtem literackim wiążą się nazwiska takich twórców, jak: Isabel Allende, Gabriel García Márquez, Álvaro Cunqueiro, Julio Cortazar, Juan Rulfo, Arturo Uslar Pietri, José de la Cuadra, Pablo Neruda). Ale w kategoriach magicznego realizmu interpretowane bywają także utwory Franza Kafki, Bruno Schulza, Michaiła Bułhakowa czy Olgi Tokarczuk.

Twórczość, w której dochodzi do symbiozy motywów realistycznych z cudownymi, magicznymi, odnosi się także do wizualnych form artystycznych, takich jak malarstwo, fotografia, kino [Hart, Quyang 2005: 1-22; Biedermann, Gazda, Hubner 2007; Mroczkowska-Brandt 2009; Chrobak 2010]. Jak pisze T. Pindel: „Realizm magiczny [...] to nurt dający się definiować raczej w kontekście specyfiki świata przedstawionego, sposobu ukazywania rzeczywistości niż w kategoriach wyłącznie estetycznych; styl pozostaje bowiem zjawiskiem niezmiernie indywidualnym i znacząco różni poszczególnych realistów magicznych" [Pindel 2014b: 262]. Pomimo różnic między poszczególnymi twórcami, można wyodrębnić pewne kluczowe, wspólne cechy, które charakteryzują utwory zaliczane do nurtu realizmu magicznego. W klasycznych pracach poświęconych tej konwencji literackiej możemy np. odnaleźć zestawienie autorstwa Wendy B. Faris, która wyróżniła tzw. główne i poboczne cechy realizmu magicznego, postrzeganego jako nurt uniwersalny. Jako zasadnicze atrybuty W.B. Faris wymienia obecne w utworze elementy magii, których nie da się wyjaśnić $\mathrm{w}$ sposób naturalny. Chociaż przedstawiony $\mathrm{w}$ dziele świat jest niemal identyczny jak ten, w którym żyjemy, co można rozpoznać po licznych szczegółach charakterystycznych dla zwykłego, codziennego życia, to jednak czytelnik miewa trudności z rozumieniem opisywanych zdarzeń i często waha się w interpretacji czy dana sytuacja jest cudem, czy też po prostu złudzeniem bohatera. 
Charakterystyczne jest ponadto poddawanie w wątpliwość tradycyjnie rozumianych kategorii czasu, miejsca i tożsamości. Natomiast do cech pobocznych, niefundamentalnych, W. Faris zalicza dodatkowo te, które dość często pojawiają się $w$ utworach nurtu realizmu magicznego, a wiążą się m.in. z patrzeniem na rzeczywistość z punktu widzenia dziecka, a także z przyjmowaniem perspektywy narracyjnej, w której magia i niesamowitość wiążą się z grupą ludzi, a nie z psychiką jednostki. Częstym motywem jest transformacja bohaterów oraz przyjmowanie za podstawę opowieści starych systemów wierzeń i lokalnych przesądów, lokowanie miejsca akcji na wsi i czerpanie z ludowych akcentów. Wiele tekstów podważa w jakiś sposób istniejący porządek społeczny, co może wyrażać się poprzez obecność „ducha karnawału” [za: Pindel 2014b: 241-242]. Cechę tę można interpretować $w$ Bachtinowskim rozumieniu karnawalizacji jako motywu nawiązującego do miejsca i czasu, w którym zawieszone zostają obowiązujące reguły i następuje swoiste odwrócenie porządku otaczającego świata oraz obowiązujących w nim zasad.

Jak zauważa T. Pindel, do owych dodatkowych cech, wyszczególnionych przez Faris, dodać by należało jeszcze motywy inicjacyjne oraz swoisty tygiel kultur, kulturową różnorodność, pojawiające się w wielu utworach realistyczno-magicznych [tamże: 242]. Zdaniem polskiego badacza realizm magiczny to nurt literacki kreujący światy na pograniczu realności i magii, opisujące jednocześnie namacalną rzeczywistość, jak i włączone w nią elementy magii, które jednak bynajmniej nie budzą zdziwienia czytelnika, przyjmującego perspektywę narratora i jego nieracjonalne "myślenie magiczne”. Wykreowane światy przypominają ten rzeczywisty, ale przedstawiają sferę pomiędzy rzeczywistością i fantazją, w której jawa i sen przenikają się nawzajem, tworząc spójną i naturalną jedność. Niezwykła zdarzenia harmonijnie łączą się z codziennością, zwyczajne przedmioty nabierają magicznej mocy. Tradycyjnie rozumiane kategorie czasu, miejsca, tożsamości bywają często poddawane w wątpliwość, a nadnaturalne elementy narracji nawiązują do folkloru, wykorzystując motywy i symbole kultury ludowej. Język jako tworzywo utworów, bywa zazwyczaj jasny i przejrzysty, pozbawiony formalnej ekstrawagancji, choć może się cechować pewną twórczą inwencją [Pindel 2014a: 37-47].

Odwołując się do pracy E. Camayd-Freixas, T. Pindel przypomina, iż charakterystyczne dla magicznego realizmu, mistyczne pojmowanie rzeczywistości, oznacza obecność nadnaturalnych sił manifestujących się pewnymi znakami, np. zwyczajna myśl bądź niewyrażone głośno pragnienie może mieć moc sprawczą, jest $\mathrm{w}$ stanie zainicjować jakieś działanie czy zdarzenie. Wiąże się to z kolejną istotną cechą, czyli animistycznym pojmowaniem świata, w którym wszystko co istnieje może oddziaływać na bohaterów, gdyż jest obdarzone duszą, energią i zdolnością sprawczą. Wynika z tego to, co E. Camayd-Freixas określa jako „płyn- 
ność ontologiczną" i transformację, wyrażającą się w braku różnicy między duchem i materią. Ponieważ wszystko, co istnieje posiada własną duchowość, możliwy jest "przepływ ontologiczny”. Dana istota wykreowana w realno-magicznym świecie może zmieniać nagle swą postać, zaś wszystkie istoty w tym, opartym na logice konkretu, świecie są w jakiś sposób powiązane siecią cudownych zależności [tamże: 48]. Podsumowując, T. Pindel stwierdza, iż „Realizm magiczny polega na przeniesieniu „pierwotnej”, magicznej mentalności [...] na pole literatury, przekuciu jej na konwencję estetyczną, na sposób opowiadania i pokazywania świata" [tamże: 51].

\section{Realizm magiczny w utworach Aliny Domnicz}

Poszukując motywów magicznego realizmu w analizowanych utworach autorstwa Aliny Domnicz, warto zwrócić uwagę na tytuły zamieszczonych w zbiorze opowiadań, które odzwierciedlają pewną konwencję. Otóż przyjęty przez autorkę układ i kolejność poszczególnych tekstów ukazuje stopniowe zagęszczanie magicznych elementów i wysycanie opowieści cudownymi postaciami i zdarzeniami. Jest to widoczne także w samych tytułach opowiadań, które początkowo dość krótkie - rozpoczynają się zwięzłym i konkretnym przedstawieniem bohaterów, o których będzie mowa (np. początkowe historie noszą tytuły: Opowiadanie o dziadu i babie; Opowiadanie o dwóch dziadach i o babie, która pomogła dziadom trafić do domu; Opowiadanie o dwóch babach i jednym dziadu; Opowiadanie o babach; Opowiadanie o babie i o dziadu, który pracowat cały dzień). Stopniowo jednak, w trakcie czytania kolejnych historii, przybierają one coraz to bardziej złożoną postać, pojawiają się niezwykli bohaterowie uczestniczący w cudownych zdarzeniach (np. Opowiadanie o czarownicach, dziadku, babci i o dzieciach; Opowiadanie o wiedźmie). Ostatnie opowiadania mają już bardzo złożone i wyczerpująco prezentujące treść historii tytuły, tworząc w zasadzie same w sobie odrębne, krótkie formy narracyjne, np. Opowiadanie o dobrej wróżce, o wyczarowanym zwierzu, o czterech babciach, o sześciu zaczarowanych ptakach, o dziadku, o kocie, o ośmiu zaczarowa-nych duchach i o pięciu strasznie olbrzymich myszach, które były zaczarowane, czy też Opowiadanie o zaczarowanym robocie, o dziku, który był łagodny i zaczarowany, o zaczarowanym jelonku, o zaczarowanej krowie, która umiała bardzo ślicznie tańczyć, o ślimaku, który mógł być cały czas na suchym lądzie, o zaczarowanej rybie, która umiała czynić bardzo dobre czary.

Wśród wątków noszących cechy realizmu magicznego, które zostały przeze mnie wyodrębnione w toku analizy wybranych utworów, można wymienić przede wszystkim fundamentalny element, jakim jest współistnienie i naturalne przenikanie świata realnego i magicznego, wyrażające się m.in. w działaniach 
czarodziejskich sił i przypisywaniu bohaterom nadnaturalnej mocy, którym towarzyszą liczne szczegóły charakterystyczne dla codziennego życia. Odnaleźć w nich można także bardzo istotny motyw przemiany (transformacji) bohaterów oraz towarzyszący jej motyw zagubienia i wędrówki bohaterów. Wśród tzw. wątków pobocznych charakterystycznych dla magicznego realizmu, odnajdujemy ponadto osadzenie miejsca akcji w sielskich, wiejskich krajobrazach, w otoczeniu przyrody oraz przyjmowanie perspektywy dziecka, przejawiającego myślenie magiczne i dostrzegającego niezwykłe, cudowne aspekty otaczającej rzeczywistości w pozornie zwyczajnych zdarzeniach. Kategorie miejsca, czasu i tożsamości bohaterów są zmienne, zaś perspektywa narracyjna wiąże elementy magiczne z grupą bohaterów, uczestniczących w różnych sytuacjach i zdarzeniach, a nie z psychiką jednostek. Poniżej omówię poszczególne wątki, ilustrując je przykładowymi fragmentami tekstów.

Współistnienie i naturalne przenikanie świata realnego i magicznego, można dostrzec m.in. w sposobie przedstawiania miejsc, w których autorka osadziła swoich bohaterów. Są to typowe, zwyczajne krajobrazy pól, lasów, łąk, gór i dolin, rzek i potoków, jezior, wiosek i miasteczek, dróg, mostów i polnych kamieni, małych domków z ogródkami, w których mieszkają bohaterowie. Miejsca te często emanują wręcz idylliczną, a jednocześnie na swój sposób, swojską atmosferą. Pojawiają się tam także „«bajkowe krainy» [...] leżące za lasami, za rzekami, za górami, za morzami”. „Krainy, w których mieszkają tylko dobre Baby Jagi, które robiły dobre czary". Opowiadane historie dzieją się w nieokreślonym czasie i miejscu, gdzieś „dawno, bardzo dawno temu, za lasami, za rzekami, za górami, za morzami”.

Głównymi bohaterami opowiadań są dziad i baba, pojawiający się w różnych konfiguracjach (jeden dziad i jedna baba, ale też dziad i dwie baby, dwa dziady i baba itp.). Inne określenia opisywanych postaci to np. „dobra, stara babcia”, "ten jakiś dziad” czy „niedobry dziad”. W analizowanych utworach pojawiają się również dzieci, zwierzęta, różne stwory, dobre i złe czarownice, czarodzieje i wróżki, duchy, kilkumetrowy zaczarowany robot, zaczarowana kukiełka, zaczarowany pajacyk, dziesięciogłowy smok z dwudziestoma nogami i wielkimi, zaczarowanymi skrzydłami. Bohaterowie Aliny Domnicz robią rzeczy zwyczajne, podobnie jak większość ludzi w realnej rzeczywistości, tzn. śpią, przygotowują posiłki, jedzą, rozmawiają, opowiadają śmieszne historie, chodzą na spacery i jeżdżą na wycieczki, oglądają zdjęcia, filmy, czytają książki (np. dziad czyta babom na głos opowiadanie), robią zakupy, chorują, pracują, odwiedzają ich goście, chodzą do kościoła, jadą na wakacje, opalają się i chlapią w wodzie, wchodzą na górskie szczyty i podziwiają widoki. Ale robią także rzeczy zaskakujące, nieco dziwne, z nie do końca znanych powodów, np. nagle wychodzą i wędrują w świat, sami nie wiedząc dlaczego; dziad znika niespodziewanie w czasie wycieczki; dziad/baba 
zagapiają się i wpadają do rzeki lub potoku, a potem chorują; dziadowi i babie coś im odbija i szaleją. Ukazują to np. takie fragmenty tekstów:

"Któregoś dnia wszystkim coś odbiło i skakali do upadtego aż do kolacji"; "[...] podszedt do okna... i pomyślat, że to ida jakieś zjawy, bo dtużej sobie pospał od bab. Baby zrobity śniadanie $i$ śmiały się z dziada, że ich nie poznat... Dopiero po obiedzie dziad poznat dwie baby $i$ sam się śmiat, że ich nie poznat wcześniej".

A dlaczego nie poznał?

"[...] bo baby się odstrzelity i wskoczyty w takie łachy, w jakich dziad ich jeszcze nigdy nie widziat. Rano dziad się obudzit i nie wiedziat, co się stało, że wszyscy leża na podłodze".

W jednym z opowiadań, przyjeżdża do nich z wizytą gość, który ni stąd, ni zowąd po prostu robi obiad, a domownicy siedzą w tym czasie na podłodze gdyż tak mocno się śmiali, że pospadali z krzeseł. Bohaterowie zachowują się niekonwencjonalnie, tak jakby to co robią było oczywiste i naturalne, np.:

"Szukat dziad drogi do domu tak długo, że już nie miat sit, i poszedt do jakiejś baby na obiad"; „[...] Po śniadaniu poszty na spacerek, na tym spacerku spotkaty jakąś babę i zapytały się: Babo, dokąd idziesz? A baba powiedziała: Idę do waszego domku zamieszkać z wami. Wszystkie cztery baby wrócity do domu i pokazaly piatej babie, jak mieszkaja".

W świecie, w którym magia i rzeczywistość przenikają się nawzajem, bardzo wyraźny jest motyw działania czarodziejskich sił i przypisywania bohaterom nadnaturalnej mocy, który wyraża się między innymi tym, że bohaterowie posiadają cechy i/lub umiejętności, których w realnej rzeczy-wistości nie mają (np. myszy są olbrzymie, zwierzęta mówią, ryby czynią dobre czary, krowy tańczą), a jednocześnie zarówno realistyczni (baba, dziad, babcia, dzieci), jak i magiczni bohaterowie (zaczarowane zwierzęta i stwory) zachowują się w podobny sposób i przydarzają się im podobne zdarzenia, tzn. gubią drogę, wpadają do wody, odbija im bez powodu, śpiewają, idą na spacerek, jedzą kolację, są zmęczeni, idą spać. Przedstawia to np. poniższy fragment jednego z opowiadań:

"[...] po jakimś czasie dwie czarownice przyszły do dziada i powiedziały mu żeby wyszedt ze swojego domku. Dziad wyszedt z domku, zobaczyt, że domek zniknąt..."; "Wieczorem dziadek poszedt na spacer z wyczarowanym zwierzakiem, potem pogłaskat dwa ptaki i wzbił się bardzo wysoko. Leciał dziadek z ptakami nad wioskami, górami, lasami, takami, rzekami i miastami dwa dni"; ,[...] a czarodziej wyczarowat kukiełke, która tadnie grała. Po skończonym graniu czarownica z kukiełką i z czarodziejem poszli spać"; ,[...] wyczarowana kukiełka ślicznie wszystkim zagrała, a później razem z niedźwiadkiem, zajączkiem i zaczarowanymi duchami opowiadała bardzo dtugie i ciekawe opo-wiadania; Czarownica wyczarowała zaczarowanego pajacyka, który tadnie tańczył i skakat tak wysoko, że dostawał swoja gtowa do sufitu, a potem wszyscy poszli spać; Rano czarownica wstała pierwsza i zobaczyła przez okno chłopczyka idącego z jakaśs olbrzymiq mysza, która była zaczarowana"; "I wyczarowała ptakowi olbrzymi dom, a w domu wyczarowała olbrzymie legowisko dla ptaka". 
Postaci stworzone przez Autorkę są w stanie spowodować nadnaturalne zjawiska, np. sprawić by dom stał się śliczny i kolorowy, powiększył się albo nagle zniknął lub przeniósł się w inne miejsce. Potrafią wyczarować pojazd, gdy jest potrzebny, instrument, który sam gra, zamienić statek w samolot, a z olbrzymiej ryby wyczarować dobrą Babę Jagę. Jednocześnie zaczarowane duchy potrafią nie tylko pięknie śpiewać, ale też „opowiadać bardzo śmieszne i ciekawe kawały” albo nagle im odbija i szaleją tak samo jak baby i dziady.

W światach wykreowanych przez Alinę Domnicz widoczny jest przepływ energii, duchowości, mocy sprawczej, którymi obdarzone są wszystkie istoty, co wynika z animistycznego pojmowania rzeczywistości i cechuje się, wedle określenia E. Camayd-Freixas, swoistym „ontologicznym przepływem” oraz transformacją, wyrażającą się w braku różnicy między duchem i materią. Każdy element tego świata może posiadać własną duchowość, dana istota może zmieniać nagle swą postać, zaś - w świecie opartym na logice konkretu - wszystkie są jednocześnie w jakiś sposób powiązane siecią cudownych zależności [Pindel 2014a: 48-51]. Wszystkie też biorą udział w podobnych sytuacjach i zdarzeniach, podlegają tym samym regułom rządzącym światem, np. w jednym z opowiadań wiedźma: „poleciała daleki świat, zobaczyła jakąś babcię z dziadkiem i chciała ich w coś zamienić, ale nie zmieniła, bo przyleciały jakieś olbrzymie stwory i zabrały ją do swojego królestwa na takiej czarodziejskiej górze, z której nie mogła zejść". W innej historii autorka z kolei pisze:

„Po jakimś czasie wszystkie stwory, które mieszkały na czarodziejskiej górze, z której nie można było zejść, zaczarowane duchy, wielkie zaczarowane myszy, zaczarowana sarenka, zaczarowany tygrysek, zaczarowany lew, olbrzymia baba ze swoim olbrzymem, których wiedźma zmienita w trochę większych od siebie, babcia, dziadek i olbrzymi zaczarowany ptak zamieszkali razem $z$ wiedźmą".

Motyw przemiany bohaterów i wędrówki bohaterów zarówno przemiany w sensie moralnym, jak i transformacji postaci, która nabiera nagle magicznej mocy i uruchamia nadnaturalne, irracjonalne działania, obecny jest w sytuacjach z pozoru zwyczajnych, gdy np. dziad zmienia się po powrocie do domu czy też pewnego dnia do dobrej wróżki przychodzi ,jakiś dziadek, z którym stało się coś dziwnego". Ale na szczęście wróżka „uczyniła swoimi czarami takie cuda, że dziadek stał się taki, jaki był zawsze”. W jednym z opowiadań „niedobry dziad” zabiera czarownicom jedzenie, ale potem przeprasza, oddaje je i po pewnym czasie staje się dobry, tak że czarownice zapraszają go by z nimi zamieszkał, a właściwie po części zmuszają do tego, powodując nagłe zniknięcie jego domku. Alina Domnicz pisze np. 


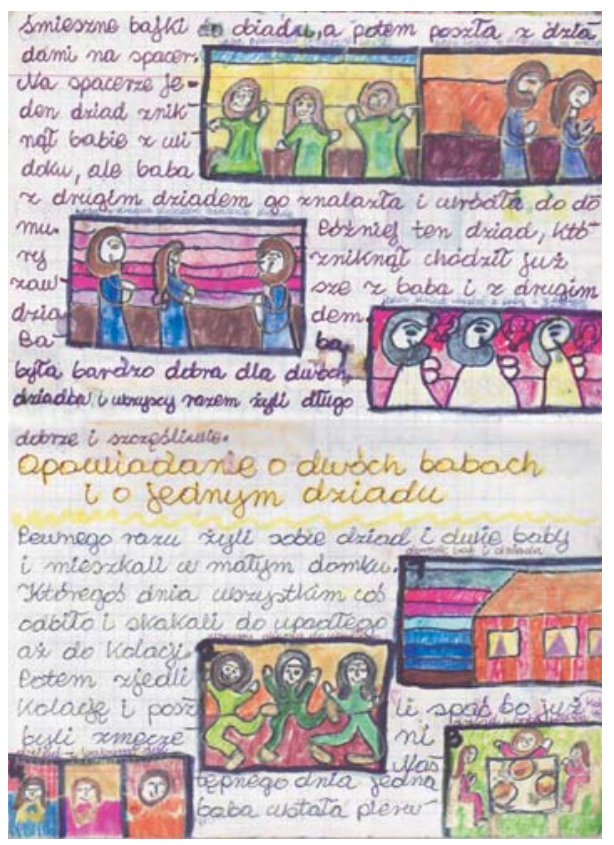

Fotografia 3

Źródło: Rękopisy Aliny Domnicz (własność Autorki, zdjęcia: Rafał Ślusarczyk)

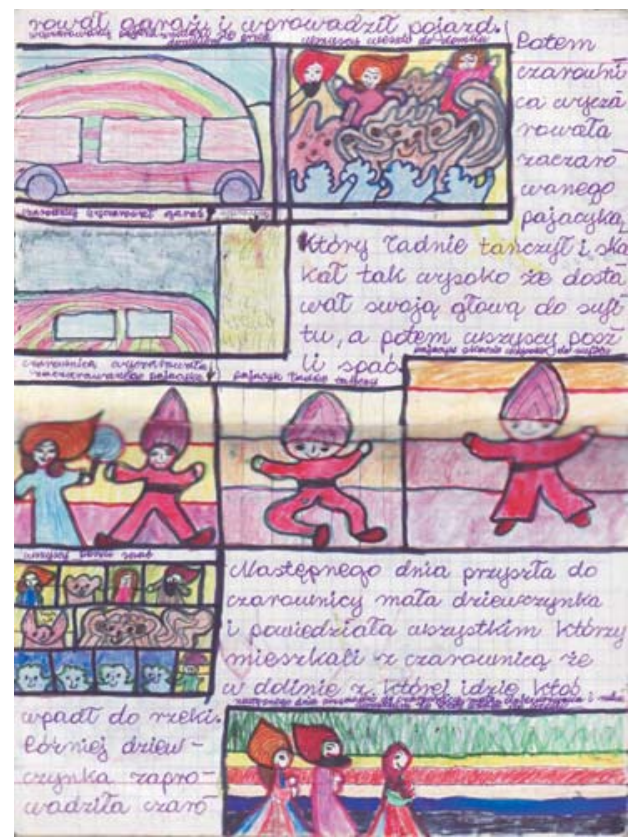

Fotografia 4

Źródło: Rękopisy Aliny Domnicz (własność Autorki, zdjęcia: Rafał Ślusarczyk) 
"Stwory przeniosty wiedźmę do jej królestwa, tam stała się dobra wiedźma i wyczarowała tym stworom dużą ksiażkę". "Któregoś dnia przyszedt do dobrej wróżki jakiś dziadek, z którym stato się coś dziwnego. Później dobra wróżka uczynita swoimi czarami takie cuda, że dziadek stat się taki jak zawsze"; "[...] W połowie dnia przywędrowaty strasznie olbrzymie myszy, których było pięć, i po chwili coś się stało z tymi myszami i zaczęty tak skakać, że niedużo brakowało do przewrócenia domku".

W ostatnim opowiadaniu autorka pisze o zaczarowanej rybie, która pewnej nocy

"[... [ się zmieniła w stwora, który latał po całym domu przez dwa tygodnie i śpiewat tak głośno, że robot nie mógt spać z wszystkimi zwierzątkami".

Ale potem przeprosiła robota i zwierzątka i namalowała im bardzo ładny obrazek, który robot powiesił na ścianie.

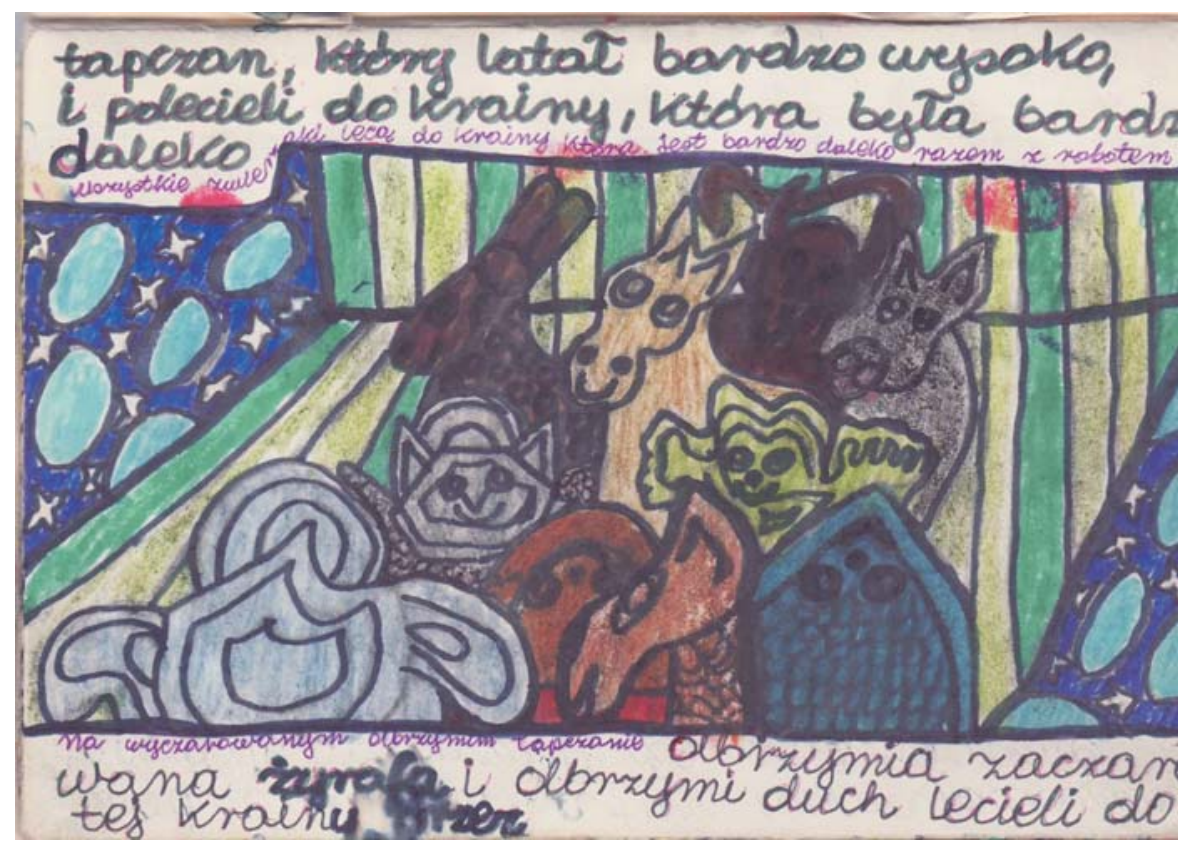

Fotografia 5

Źródło: Rękopisy Aliny Domnicz (własność autorki, zdjęcia: Rafał Ślusarczyk)

Motyw wędrówki bohaterów pojawia się w powtarzalnych wątkach opowieści, w których to dziad bądź dziady wędrują po świecie; baby, dziady, dzieci gubią drogę, błądzą i trafiają do domku albo wpadają do wody; baba szuka dziada i dziadów. Towarzyszy mu motyw zagubienia się przez bohaterów oraz działań związanych 
z poszukiwaniami i pomocą $\mathrm{w}$ odnalezieniu drogi i powrocie do domu. Często odnalezienie schronienia na nocleg ma charakter przypadkowy i cudowny, np.

„[...] szukali tak dlugo, aż zrobiło sięciemno, zobaczyli domek, w którym się śwwieciło, i poszli do tego domku przenocować. [...] doszli do domku, w którym mieszkała baba i poszli do tej baby na obiad".

W świecie Aliny Domnicz wędrują i gubią się także niezwykli, obdarzeni nadnaturalnymi mocami, czarodziejscy bohaterowie opowiadań, np.

"Następnego dnia wiedźma wzięła miottę i poleciata na tej miotle na wycieczkę, która trwała dwa tygodnie. Na tej wycieczce spotkata zaczarowanego lwa, a potem pomylita drogę i nie mogła trafić do domu. Po jakimś czasie zobaczył wiedźmę olbrzymi, zaczarowany ptak, który przyleciat do wiedźmy i powiedziat, że pomoże jej trafić do czarodziejskiego domku, w którym mieszka".

$\mathrm{W}$ innym opowiadaniu, bohaterowie (dziadek z wyczarowanym zwierzakiem i czterema babciami) dostrzegają przez okno olbrzymiego zaczarowanego słonia, który „pomylił sobie drogę” i proponu-ją mu by z nimi zamieszkał. W kolejnej historii,

"Któregoś dnia do robota przywędrował dzik, który był łagodny, powiedziat robotowi, że pomylit sobie drogę i nie może trafić do swojego domku".

Robot zaprosił go do siebie i zamieszkali razem.

P. Huelle zauważa, że aby odnaleźć swoje szczęśliwe miejsce i czas, bohaterowie opowieści Aliny Domnicz muszą najpierw wyruszyć w drogę, pokonać przeszkody, znaleźć przyjazną duszę. Ten nieomal obsesyjnie przewijający się w różnych układach i sytuacjach motyw powraca za każdym razem by pokazać wysiłek wkładany w relacje z innymi ludźmi oparte na przyjaźni i miłości, a nie rywalizacji i odrzuceniu. Może więc być interpretowany jako wyobrażenie/pragnienie takiej właśnie rzeczywistości, odmiennej niż realny świat, w którym żyjemy. Rzeczywistości, w której wiele się wydarza, ale która jednak zawsze prowadzi do szczęśliwego zakończenia i obdarza wewnętrznym spokojem i harmonią. „Dom, las, jezioro, spacer - oto przestrzeń, w której bohaterowie tych opowieści, po licznych wędrówkach i powrotach, odnajdują szczęśliwie swoje miejsce", pisze P. Huelle [1996: 3-4]. Czyż nie wyraża to marzenia większości z nas?

\section{Zakończenie - narracja, kreacja i życie}

L. Leal pisał, iż realizm magiczny w literaturze nie skupia się na formie i zabiegach estetycznych i przyjmuje zarówno formy proste, ludowe jak i wyszukane, może przejawiać się w stylu dopraco-wanym, ale też pospolitym. T. Pindel doda- 
je, iż język utworów z tego nurtu często bywa ",jasny i przejrzysty, pozbawiony formalnej ekstrawagancji", słowne tworzywo opowieści jest też kwestią bardzo indywidualną [Pindel 2014a: 27-28; 2014b: 225-227]. Alina Domnicz, w poddanych analizie Opowiadaniach, używa niezbyt skomplikowanego, dość potocznego, a miejscami nawet lekko rubasznego języka, zamykającego się w stosunkowo niewielkim zbiorze pojęć, zwrotów i zdań. Od strony formalnej można go odczytywać w kategoriach charakterystycznych dla ograniczonego kodu językowego w rozumieniu B. Bernsteina [Krzemińska 2012: 199-219]. W jej opowiadaniach nie znajdziemy złożonych fraz czy też skomplikowanych metafor i związków frazeologicznych, pojawiających się w twórczości latynoamerykańskich mistrzów pióra czy współczesnych pisarzy. Jednak za pomocą prostego, pozbawionego intelektualnego wyrafinowania i estetycznych eksperymentów tworzywa, potrafi wykreować coraz to bardziej złożoną, nabierającą magicznego wymiaru rzeczywistość. Wprowadza w tok opowieści, dozując niejako stopniowo napięcie, niezwykłych bohaterów, których umieszcza w pozornie zwyczajnych i naturalnych, ale zarazem też dziwnych i niezwykłych sytuacjach. Powtarzające się, schematyczne wątki przewijające się w kolejnych opowieściach, można oczywiście odebrać jako wadę tekstu, wynikającą choćby $\mathrm{z}$ ograniczeń poznawczych i językowych powiązanych z niepełnosprawnością. P. Huelle, dostrzegając pewne poczucie monotonii i schematyzmu, obecne w Opowiadaniach Aliny Domnicz, proponuje interpretację odnoszącą się do osobistego przekazu widzenia świata i ludzkich problemów takimi, jakimi widzi je autorka. Charakteryzując bohaterów jej historii pisze, iż są to „postacie zupełnie pozbawione rysów indywidualnych, klasyczni, bajkowi dziad i baba, czarownica, chłopiec. [...] są raczej figurkami w lalkowym teatrze, poruszane nie wiedzieć przez kogo ani dlaczego" [Huelle 1996: 4]. Można jednak tę cechę powiązać z właściwościami charakteryzującymi nurt magicznego realizmu, $\mathrm{w}$ którym zdaniem często przyjmowana jest perspektywa narracyjna łącząca elementy magiczne z grupą bohaterów, uczestniczących $\mathrm{w}$ różnych sytuacjach i zdarzeniach, a nie z indywidualną psychiką jednostek.

Schematyczne, niemal obsesyjnie powtarzające się zwroty stanowią zarazem specyficzny atrybut, nadający kolejnym historiom określony rytm. Wątki tematyczne pojawiają się $w$ tekstach $w$ różnych konfiguracjach, ukazując stopniowo coraz bardziej złożony świat i bohaterów, którym przytrafiają się zwyczajne, jak i niezwykłe zdarzenia. Powoli, w nieoczywisty sposób, wciągają czytelnika w magiczny świat, z pozoru dość nudny i monotonny, ale zarazem przeniknięty jakąś tajemnicą, pełen zdarzeń, spotkań, działań, przygód i relacji między bohaterami. Zdaniem L. Leala, realizm magiczny nie tworzy fantastycznych światów, do których można uciec, lecz raczej „wychodzi naprzeciw rzeczywistości” i próbuje sięgnąć do jej wnętrza. Czytając cały zbiór opowiadań, od początku do końca, możemy prześledzić uruchamianie kolejnych warstw opowieści i stopniowe wysyca- 
nie rzeczywistości elementami magicznymi. W końcowych opowiadaniach znajdujemy się już w bajkowym, zaczarowanym świecie, w którym wszystko może się zdarzyć, ale który jest również silnie zakorzeniony w potoczności codziennych sytuacji. Na ludzkie życie składają się przecież chwile cudowne i niepowtarzalne, ale też zdarzenia, które przez swą rytmiczną powtarzalność bywają przesycone monotonią.

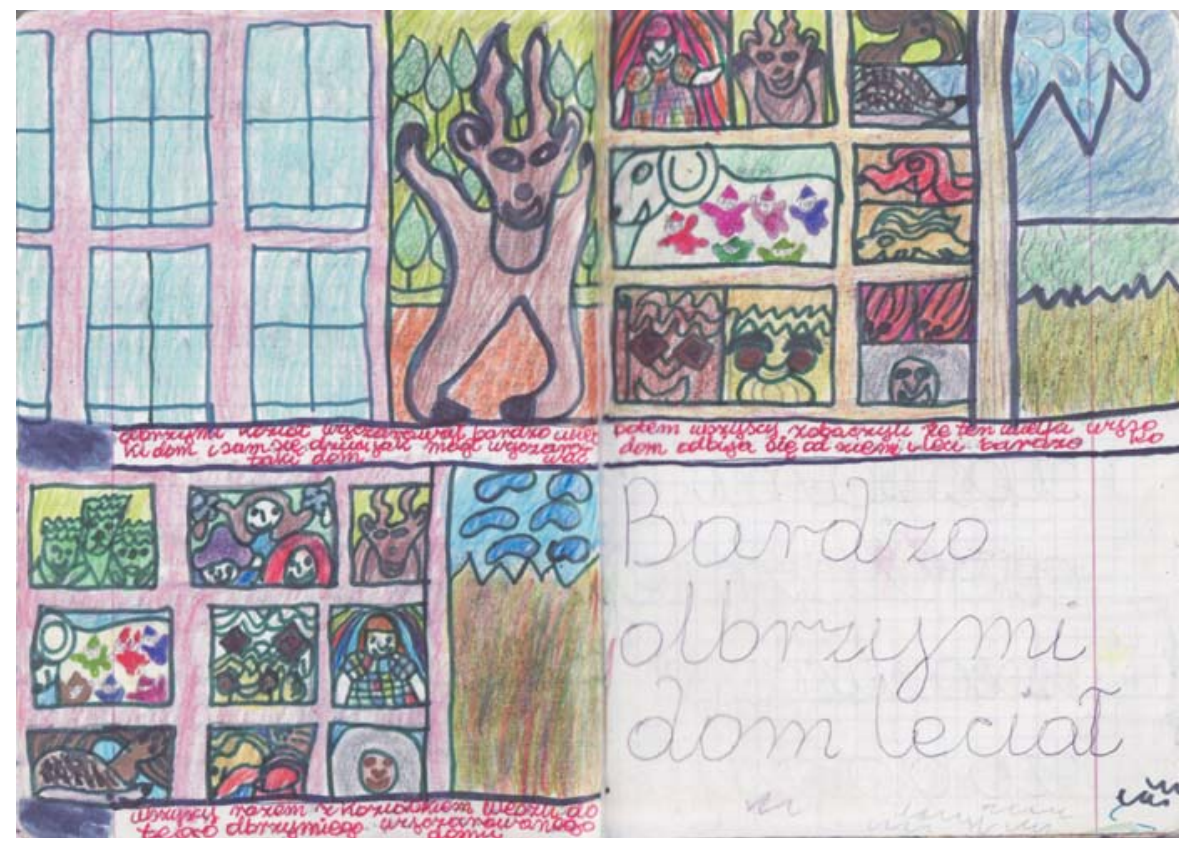

Fotografia 6

Źródło: Rękopisy Aliny Domnicz (własność autorki, zdjęcia: Rafał Ślusarczyk)

Opowiadania Aliny Domnicz ukazują rzeczywistość, w której główni bohaterowie są najczęściej dorosłymi ludźmi lecz ich sposób doświadczania i przeżywania świata często ukazywany jest z dziecięcej perspektywy, wypełniony zabawą, wędrówkami, przygodami, emocjami i uczuciami oraz niezwykłymi, czarodziejskimi postaciami, posiadającymi nadzwyczajne moce. T. Pindel określa magiczny realizm jako „przeniesienie pierwotnej, magicznej mentalności na pole literatury, przekucie jej [...] na sposób opowiadania i pokazywania świata" [Pindel 2014a: 51]. Autorka, zapraszając nas do wykreowanego przez siebie literackiego świata, być może wyraża własne przeżycia, emocje i pragnienia, dzieli się z nami swoim charakterystycznym widzeniem rzeczywistości, wynikającym z osobistych doświadczeń i uwarunkowań biograficznych. A może owa rzeczywistość jest autorską kreacją, w której życia nie można utożsamiać z narracją i sposobem na 
przepracowanie traum, choć oczywiście może tak być, gdyż w pewnym sensie każde dzieło sztuki i utwór literacki jest wypadkową percepcji świata, przeżyć i doświadczeń jego autora/ki? Może jest to, jak pisze P. Huelle, inspirowana pragnieniem „uczynienia świata bardziej znośnym, oswojonym przez naszą wyobraźnię, słowo, twórczy akt kreacji”, opowieść o krainach, w których baby, dziady, dzieci i zwierzęta, wiedźmy, czarownice, kukiełki, smoki i roboty zgodnie koegzystują na pograniczu realności i magii? Realny świat tak nie wygląda, ale może Alina Domnicz takim właśnie chciałaby go widzieć i w zwyczajnej codzienności dostrzegać to, co bywa cudowne?

Podziękowania: Chciałabym złożyć serdeczne podziękowania Pani Alinie Domnicz, której wycinek twórczości starałam się przedstawić w prezentowanym artykule, za przychylne przyjęcie i akceptację tego pomysłu oraz udostępnienie fotografii jej autorskich brulionów. Dziękuję także Panu Rafałowi Ślusarczykowi, dyrektorowi Wspólnoty L'Arche w Śledziejowicach, za pomoc w kontakcie $\mathrm{z}$ autorką i wykonanie fotografii.

\section{Bibliografia}

Bal M. (2012), Narratologia. Wprowadzenie do teorii narracji, Wydawnictwo Uniwersytetu Jagiellońskiego, Kraków.

Bauman T. (2001), Strategie jakościowe w badaniach pedagogicznych [w:] Zasady badań pedagogicznych, T. Pilcha, T. Bauman (red.), Wydawnictwo Akademickie "Żak”, Warszawa.

Biedermann J., Gazda G, Hubner I. (red.) (2007), Realizm magiczny: teorie i realizacje artystyczne, Wydawnictwo Uniwersytetu Łódzkiego, Łódź.

Chrobak M. (2010), Realizm magiczny w polskiej literaturze dzieci i młodzieży, Wydawnictwo Naukowe UP, Kraków.

Domnicz A. (1996), Opowiadania, PSOUU i Galeria Promyk, Gdańsk.

Hart S.M., Ouyang W.Ch. (eds.) (2005), A Companion to Magical Realism, Woodbridge, Tamesis.

Hulle P. (1996), Przedmowa [w:] A. Domnicz, Opowiadania, Gdańsk, s. 3.

Krzemińska D. (2012), Język i dyskurs codzienny osób z niepetnosprawnością intelektualną, Oficyna Wydawnicza „Impuls”, Kraków.

Krzemińska D. (2013), „Mam wrażenie, że Anieli niosa mnie wszędzie...”. Karol Nahlik w (nietypowej) refleksji, „Niepełnosprawność”, nr 9, s. 72-92.

Mroczkowka-Brandt K. (2009), Przeczucia innego porządku. Mapa realizmu magicznego w literaturze światowej XX i XXI wieku, Wydawnictwo Uniwersytetu Jagiellońskiego, Kraków.

Palska H. (1999), Badacz społeczny wobec tekstu. Niektóre problemy analizy jakościowej w socjologii i teorii literatury [w:] Spojrzenie na metodę. Studia z metodologii badań socjologicznych, H. Domański, K. Lutyńska, W. Rostocki (red.), IFIS PAN, Warszawa.

Perakyla A. (2009), Analiza rozmów i tekstów [w:] Metody badań jakościowych, N.K. Denzin, Y.S. Lincoln (red.), PWN, Warszawa.

Pindel T. (2014), Realizm magiczny. Przewodnik (praktyczny), Universitas, Kraków. 
Pindel T. (2014), Zjawy, szaleństwo i śmierć. Fantastyka i realizm magiczny w literaturze hispanoamerykańskiej, Universitas, Kraków.

Silverman D. (2007), Interpretacja danych jakościowych, PWN, Warszawa.

Szczepaniak K. (2012), Zastosowanie analizy treści w badaniach artykułów prasowych, „Acta Universitatis Lodziensis. Folia Sociologica", nr 42, s. 83-112.

Szemplińska A., Chatzipedtidis K. (2017), Zastosowanie Biblioterapii z osobami z niepetnosprawnościq intelektualna na przykładzie Wspólnoty L'Arche, „Edukacja Humanistyczna”, nr 1, s. 161-170.

Wlazło M. (2013), Proste myśli, trudne słowa. Z perspektywy socjopedagogicznej o wizerunku osób z niepetnosprawnościq intelektualna w literaturze pięknej, Oficyna Wydawnicza "Impuls”, Kraków, s. 14.

Zierkiewicz E., Szemplińska A. (2015), Czarownica jako alter ego dojrzałej kobiety z niepetnosprawnością intelektualna. Analiza autorskich bajek, „Edukacja Dorosłych”, nr 2, s. 123-141. 